\title{
GARNETS FROM ALTAY, CHINA
}

\author{
By Fuquan Wang and Yan Liu
}

\begin{abstract}
Gem-quality spessartine garnet and grossular garnet have been discovered in Altay, China. Gemological and mineralogical studies show that their properties are typical for these garnet species. Spessartine and grossular are being mined commercially, but gem-quality grossular with fine color is rare.
\end{abstract}

The Altay Mountain Range has long been known in China as the "native place of gemstones." For dozens of years, gem-quality varieties of apatite, beryl, spodumene, topaz, and tourmaline have been mined there. Gem-quality spessartine garnet (figure 1) was discovered at the Qibeiling mine in 1950. Since then, it has been recovered as a byproduct of quartz mining. In 1980, gem-quality grossular garnet (figure 2) was discovered about 30 $\mathrm{km}$ (18 miles) northwest of the Qibeiling mine at what is now known as the Cocoktau mine. The brown to reddish brown grossular is known by the variety name hessonite; the green variety is referred to in China as "Altay emerald" (Keller and Wang, 1986; Wang, 1986).

This article briefly reviews access to, and geol-

\section{ABOUT THE AUTHORS}

A gemologist and mineralogist, Dr. Wang recently retired as research professor at the Geological Museum, Beijing, China. His book, Gems and Gem Appraising, has just been published in Chinese. Mr. Liu is a research associate in the Research Department, Gemological Institute of America, Santa Monica, California.

Acknowledgments: The authors thank Mr. Chen Wenao for arranging the visit to the Altay mines, providing samples, and drawing the original geologic map of the Cocoktau deposit. Mr. Guo Jiugao did the ultraviolet-visible spectral measurement of the grossular sample. Dr. James E. Shigley and Dr. Emmanuel Fritsch of GlA Research provided helpful comments.

Gems \& Gemology, vol. 29, No. 4, pp. 273-277

(C) 1994 Gemological Institute of America ogy of, these two relatively new sources of garnets, about which little has been written in the Western literature. The gemological characteristics and chemical composition of both spessartine and grossular garnets from the two mines are described.

\section{LOCATION AND ACCESS}

The Altay Mountain Range is north of the Xinjiang Uygur Autonomous Region in remote, sparsely populated northwest China, adjacent to Mongolia and Kazakhstan (figure 3). The Qibeiling and Cocoktau deposits lie, respectively, about $45 \mathrm{~km}$ and $70 \mathrm{~km}$ (27 and 42 miles) northwest of Altay City (approximate population: 100,000; see again figure $3 /$ in mountainous terrain. Both can be reached via graded dirt roads for only about six months each year, between April and October.

Figure 1. Spessartine garnets recovered from the Qibeiling mine include these faceted stones, which range from 3.5 to $5.5 \mathrm{ct}$. Photo by Robert Weldon.

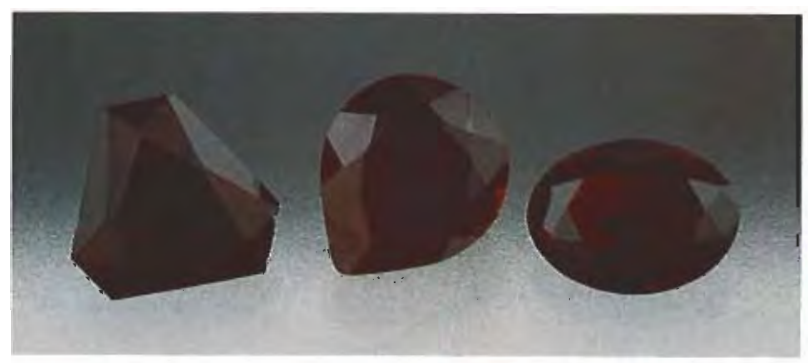




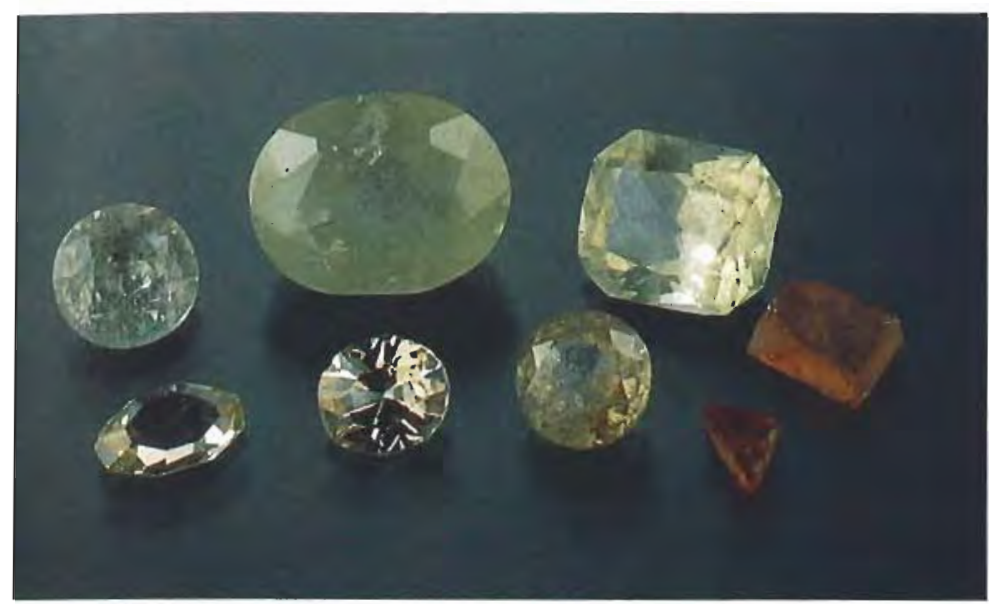

Figure 2. Gem-quality grossular garnet from the Cocoktau mine is found in various colors, as illustrated by these faceted stones and pieces of rough ranging from about 0.5 to $6.5 \mathrm{ct}$. Photo by Robert Weldon.

Heavy snowfall during the cold winters makes access treacherous if not impossible. The Qibeiling deposit covers about $400 \mathrm{~m}^{2}$, the Cocoktau deposit extends over approximately $560 \mathrm{~m}^{2}$.

Figure 3. The Qibeiling and Cocoktau deposits lie, respectively, about $45 \mathrm{~km}$ and $70 \mathrm{~km}$ northwest of Altay City (approximate population: 100,000) in mountainous terrain. Both can be reached via graded dirt roads for only about six months of the year. The inset map shows this sparsely populated region's relationship to neighboring Mongolia and Kazakhstan. Artwork by Carol Silver.

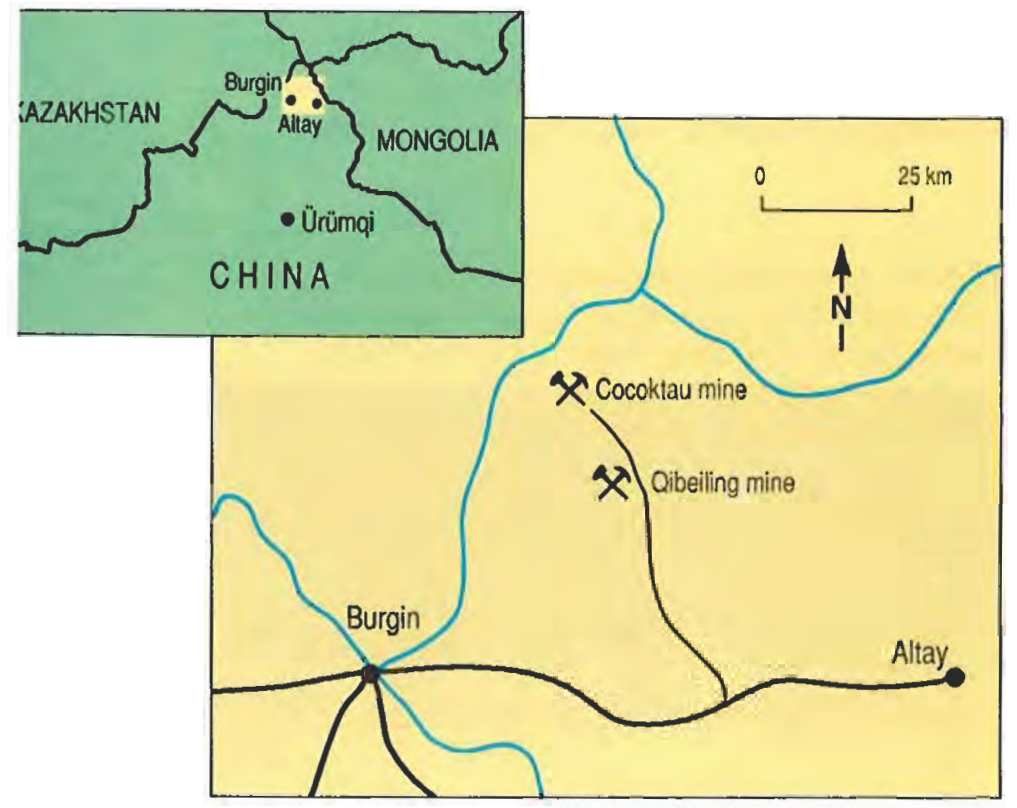

\section{GEOLOGY AND OCCURRENCE}

At Qibeiling, a spessartine-bearing pegmatite intruded into schistose biotite-gneiss, the region's country rock. The spessartine occurs in the replacement zones in the inner part of the pegmatite. Associated minerals are albite /variety cleavelandite), quartz (rock crystal), schorl, and muscovite mica. Two different generations of spessartine are found. The first type is smaller, heavily included, and was the source material for the second. The first-generation spessartine, associated with the quartz, was dissolved and redeposited as the second generation, associated with the albite, through recrystallization by hydrothermal growth. This is apparent from specimens studied in various degrees of homogenization. When dissolution and recrystallization of the first generation was complete, the less-included, larger crystals of the second generation resulted. While material of the first generation is of no gemological value, because it is too small and heavily included, specimens of the latter generation are large enough-and of sufficiently high clarity - to be cut as gems.

Although quartz was the primary mineral extracted from the Qibeiling mine during the 1950s, some second-generation spessartine was also recovered. Mining stopped at a depth of about $10 \mathrm{~m}$. Further mining would have necessitated widening the main pit, a task deemed impractical. In the late 1970s, miners found high-quality spessartine--that is, the second type referred to previously-in a pocket within the albite-rich replacement zone of the pegmatite. Over $1,000 \mathrm{~kg}$ of spessartine have been recovered since then, about $20 \%$ of which is facet grade.

Grossular occurs at Cocoktau in skarns within marble in the form of bands, pockets, and rounded massive bodies, which extend approximately parallel to the general trend of the country rocks. Gemquality material is mostly found in the middle part of the calcium-rich zones within the skarns (figure 4). Associated minerals were zoisite (early stage), epidote (later stage), albite, diopside, hornblende, and quartz.

Several tons of grossular rough have been recovered from the open-pit Cocoktau mine since grossular was discovered there in the 1980s (figure 5). However, only about $10 \%$ is suitable for faceting. Much of the material was either damaged by blasting when the mine was opened or was of low quality to begin with. After faceting, some of this grossular enters the world market through Hong Kong. 


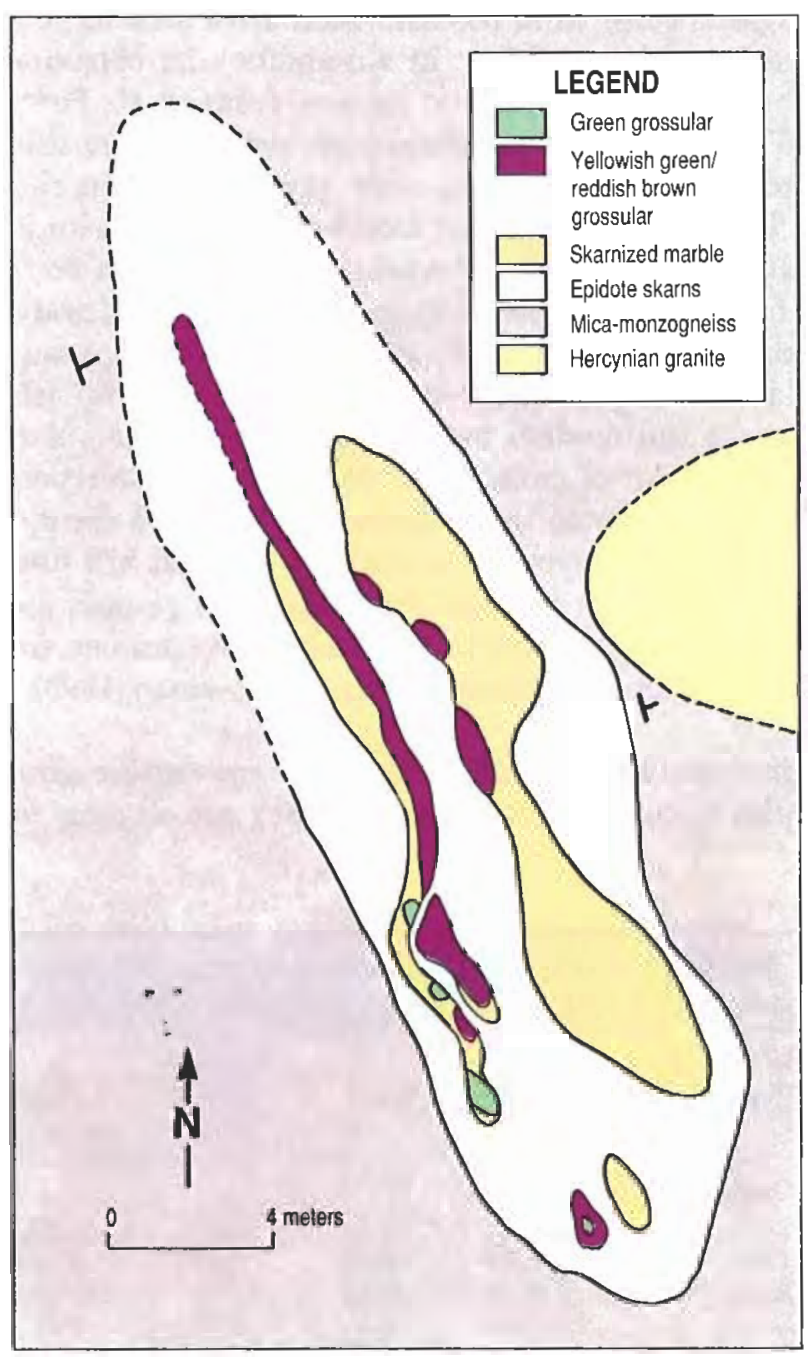

Figure 4. This geologic map of the Cocoktau grossular deposit shows the locations of gem-quality material in linear trends within the skarn zones. From a map by Chen Wenao, artwork by Carol Silver.

\section{MATERIALS AND METHODS}

We used standard gemological testing equipment to characterize about 20 polished sections each of grossular and spessartine garnet from the Cocoktau and the Qibeiling mines, respectively. Also examined were rough and faceted stones. Specific gravity was determined hydrostatically. An Hitachi U4001 spectrophotometer was used to record the absorption spectrum (in the 400- to 650-nm range) of a spessartine sample. Mr. Guo Jiugao recorded the U.V.-visible spectrum of a grossular sample. Chemical composition was determined by wet chemical analysis, using four representative samples-one brown spessartine and three grossular garnets (green, yellowish green, and reddish brown).

\section{THE GARNETS}

The spessartine garnets occur as anhedral masses (i.e., lacking crystal form). Translucent to transparent, they range from brown to reddish brown and from 5 to $100 \mathrm{~mm}\{0.2-4$ inches\} in diameter. The largest gem-quality mass found to date weighed about $1 \mathrm{~kg}$. Most of the gem-quality material is moderately included.

The grossular garnets range from 5 to $20 \mathrm{~mm}$ in diameter, and are euhedral to semi-euhedral in crystal form (figure 6). They range from green to yellow-green to greenish yellow to reddish brown. Faceted stones from both localities average 1-3 ct.

Gemological Properties. We recorded refractive indices of 1.805-1.811 for the spessartines and $1.727-1.737$ for the grossulars. The specific gravity was $4.20-4.25$ for the spessartines and 3.58-3.65 for the grossulars. Neither species reacted to longor short-wave ultraviolet radiation, and both had a Mohs hardness of about 71/2. Gemological properties of both the grossular and spessartine are within known ranges for the respective species, with some almandine $\left(\mathrm{Fe}^{2+}\right)$ component in the latter (Stockton and Manson, 1985).

Chemistry. Table 1 shows the results of the wet chemical analyses, including end-member compositions as determined by the Rickwood (1968) method. Overall compositions are typical for these garnet species.

Figure 5. The open-pit Cocoktau mine has produced several tons of grossular rough since it began operation in the 1980s; about $10 \%$ of the rough is suitable for faceting.

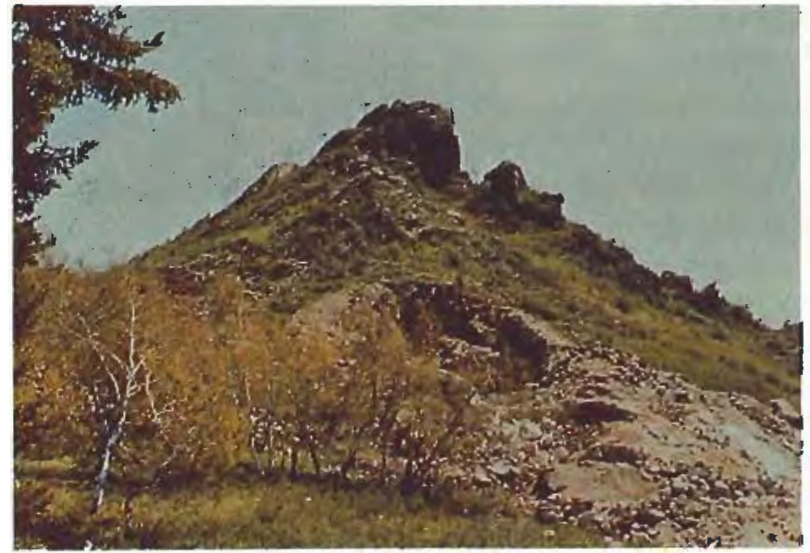




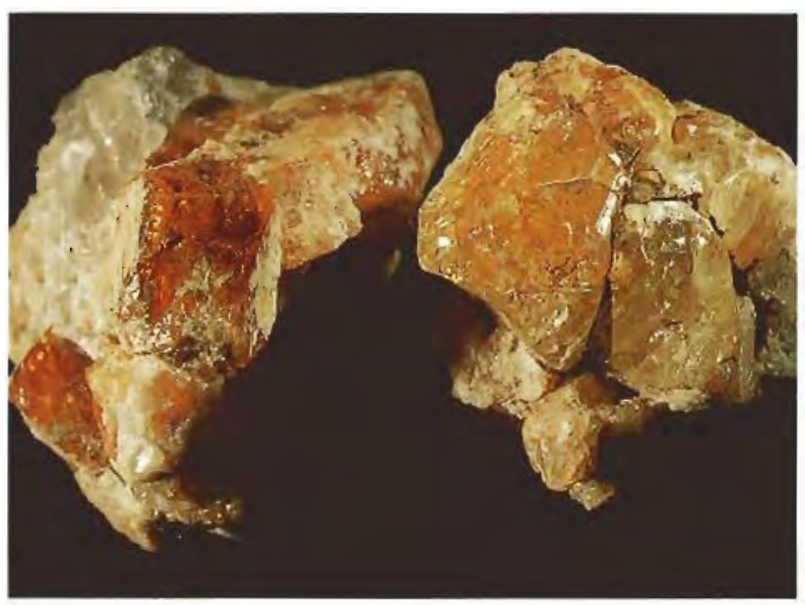

Figure 6. Garnet from the Cocolktan deposit is euhedral to semi-euhedral in crystal form, like these pieces of greenish yellow grossular (about $5 \times 5 \mathrm{~cm}$ ) and hessonite rough (about $8 \times 5 \times 5 \mathrm{~cm}$ ). Photo by Fuquan Wang.

These data indicate that $\mathrm{Fe}^{2+}$ constitutes a high proportion of the total iron content in the spessartine. The color of spessartine progresses from orange to orange-red as Fe content increases. Refractive index and specific gravity also increase with the Fe concentration, as is often the case with gem silicates (E. Fritsch, pers comm., 1993).

Chemical data for the grossular garnets further confirmed that $\mathrm{Fe}$ content was related to color; as Fe content increased, the color progressed from green to yellow-green to reddish brown. Refractive index, specific gravity, and unit-cell parameters all increased as total Fe content rose.

Spectroscopy. Figure 7 illustrates typical visiblerange absorption features found in the spessartines: bands at about 409, 422, 430,460,482, and 520 $\mathrm{nm}$. All of these absorption bands are related to $\mathrm{Mn}^{2+}$ (Manning, 1967). The three major $\mathrm{Mn}^{2+}$ absorption bands-at 409, 422, and $430 \mathrm{~nm}$-give spessartine its intrinsic, dominant $586.1-654.5 \mathrm{~nm}$ wavelength and orange color. The weak absorptions at $570 \mathrm{~nm}$ and $504 \mathrm{~nm}$ are related to $\mathrm{Fe}^{2+}$. The overall brown color component of the spessartine is due to an underlying absorption increasing toward the ultraviolet. Such absorption has been attributed to $\mathrm{Fe}^{2+}-\mathrm{Ti}^{4+}$ charge transfer (Fritsch and Rossman, 1993).

Figure 8 illustrates typical visible-range absorption features found in the grossular garnets; the absorption bands at 366, 408, and 425 have all been related to the presence of $\mathrm{Fe}^{3+}$ (Manning, 1967).
The 571-nm band has also been attributed to $\mathrm{Fe}^{3+}$ in grossular (and $\mathrm{Fe}^{2+}$ in almandine); its behavior here suggests that it is not related to $\mathrm{Fe}^{3+}$. Chromium and vanadium both also absorb in this region, although they were not detected in the chemical analyses. The increasingly brown color is also caused by an absorption-attributed to $\mathrm{Fe}^{2+}$ $\mathrm{Ti}^{4+}$ charge transfer-rising continuously toward the ultraviolet; virtually absent in the green grossular, it becomes more important in the yellowish green and reddish brown varieties. The greenish component of grossular is due to the transmission window created in the green by the broad absorption with an apparent maximum at about $570 \mathrm{~nm}$. However, the various chromogens in garnets are numerous, and their interrelationships complex; for more information, see Fritsch and Rossman (1993).

Inclusions. The inclusions in the spessartine samples occur in part as bands. They are angular or

TABLE 1. Chemical compositions and properties of one spessartine and three grossular garnets from Altay, China.

\begin{tabular}{|c|c|c|c|c|}
\hline \multirow{2}{*}{$\begin{array}{l}\text { Composition/ } \\
\text { property }\end{array}$} & \multirow{2}{*}{$\frac{\text { Spessartine }}{\text { Brown }}$} & \multicolumn{3}{|c|}{ Grossular } \\
\hline & & Green & $\begin{array}{l}\text { Yellowish } \\
\text { green }\end{array}$ & $\begin{array}{l}\text { Reddish } \\
\text { brown }\end{array}$ \\
\hline \multicolumn{5}{|l|}{ Oxide (wt. \%) } \\
\hline $\mathrm{SiO}_{2}$ & 37.01 & 39.03 & 39.40 & 39.05 \\
\hline $\mathrm{TiO}_{2}$ & 0.14 & 0.02 & 0.07 & 0.16 \\
\hline $\mathrm{Al}_{2} \mathrm{O}_{3}$ & 19.42 & 22.65 & 21.89 & 20.33 \\
\hline $\mathrm{Cr}_{2} \mathrm{O}_{3}$ & n.d. & n.d. & 0.01 & 0.01 \\
\hline $\mathrm{Fe}_{2} \mathrm{O}_{3}$ & 2.15 & 0.63 & 1.11 & 3.12 \\
\hline $\mathrm{FeO}$ & 11.03 & 0.02 & 0.23 & 0.50 \\
\hline $\mathrm{MnO}$ & 29.60 & 0.05 & 0.05 & 0.10 \\
\hline $\mathrm{MgO}$ & 0.17 & 0.14 & 0.13 & 0.30 \\
\hline $\mathrm{CaO}$ & 0.31 & 37.04 & 36.68 & 36.65 \\
\hline $\mathrm{K}_{2} \mathrm{O}$ & n.d. & n.d. & 0.02 & 0.07 \\
\hline $\mathrm{Na}_{2} \mathrm{O}$ & n.d. & n.d. & 0.01 & 0.01 \\
\hline $\mathrm{P}_{2} \mathrm{O}_{5}$ & 0.17 & n.d. & n.d. & n.d. \\
\hline $\mathrm{V}_{2} \mathrm{O}_{3}$ & n.d. & n.d. & n.d. & n.d. \\
\hline Total & $\overline{100.00}$ & $\overline{99.58}$ & $\overline{99.60}$ & $\overline{100.30}$ \\
\hline \multicolumn{5}{|l|}{ Species (wt.\%) } \\
\hline Almandine & 26.00 & n.d. & n.d. & n.d. \\
\hline Andradite & 0.96 & 1.79 & 3.05 & 8.67 \\
\hline Grossular & n.d. & 97.52 & 96.24 & 89.67 \\
\hline Pyrope & 0.73 & 0.54 & 0.49 & 1.14 \\
\hline Spessartine & 72.31 & 0.12 & 0.11 & 0.22 \\
\hline Schorlomite & n.d. & 0.03 & 0.11 & 0.30 \\
\hline Total & $\overline{100.00}$ & $\overline{100.00}$ & $\overline{100.00}$ & $\overline{100.00}$ \\
\hline \multicolumn{5}{|c|}{ Gemological property } \\
\hline Specific gravity & 4.23 & 3.60 & 3.63 & 3.65 \\
\hline Refractive index & 1.808 & 1.727 & 1.737 & 1.743 \\
\hline Hardness & $71 / 2$ & $7^{1 / 2}$ & $7^{1 / 2}$ & $71 / 2$ \\
\hline
\end{tabular}

aKnown by the gem varielal name hessonite. bAs determined by wet chemistry. 


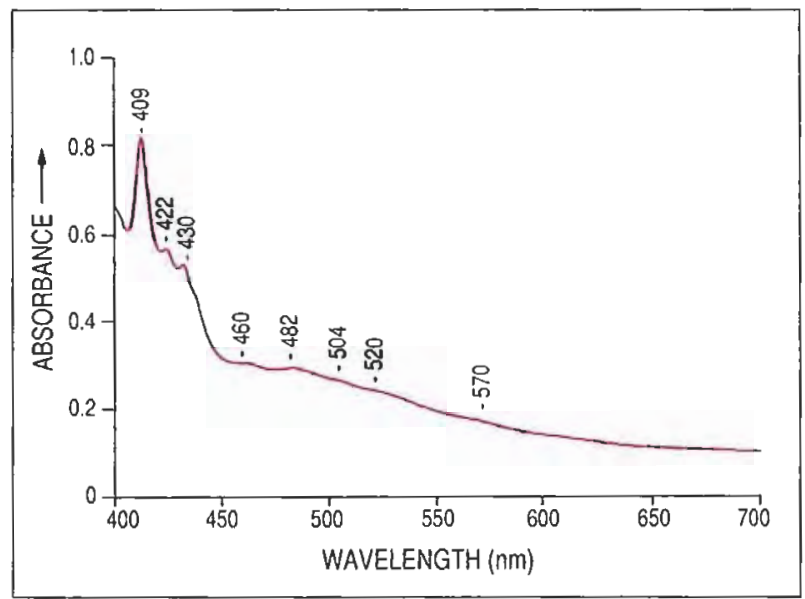

Figure 7. This visible-range optical absorption spectrum illustrates typical absorption features found in spessartine garnet from the Qibeiling mine. The three maior $\mathrm{Mn}^{2+}$ absorption bands-409, 422, and $430 \mathrm{~nm}-$-give spessartine its intrinsic color.

irregular in shape, range from 10 to $52 \mu \mathrm{m}$ in length, and are typically liquid-containing negative crystals, with about $6 \%-17 \%$ gas. The homogenization temperature of fluid inclusions in spessartine was $200^{\circ}-290^{\circ} \mathrm{C}$.

Inclusions in the grossular samples are angular or irregular in shape, 10 to $40 \mu \mathrm{m}$ in length, and typically contain both gas and liquid phases (figure 9). The homogenization temperature of inclusions in green grossular was $200^{\circ}-240^{\circ} \mathrm{C}$; that of inclusions in zoisite-the principal associated mineralwas $300^{\circ} \mathrm{C}$.

\section{CONCLUSION}

Significant quantities of spessartine occur in the pegmatite at Qibeiling and are now being mined commercially; about $20 \%$ is facet grade. All of the gem-quality spessartine garnets represent secondgeneration growth. Several tons of grossular have been recovered from Cocoktau since 1980, but only about $10 \%$ is gem quality. Material of fine green color is rare. Production at both localities will continue for many years. Currently, the material is cut in China. It is sold locally and, through Hong Kong, internationally.

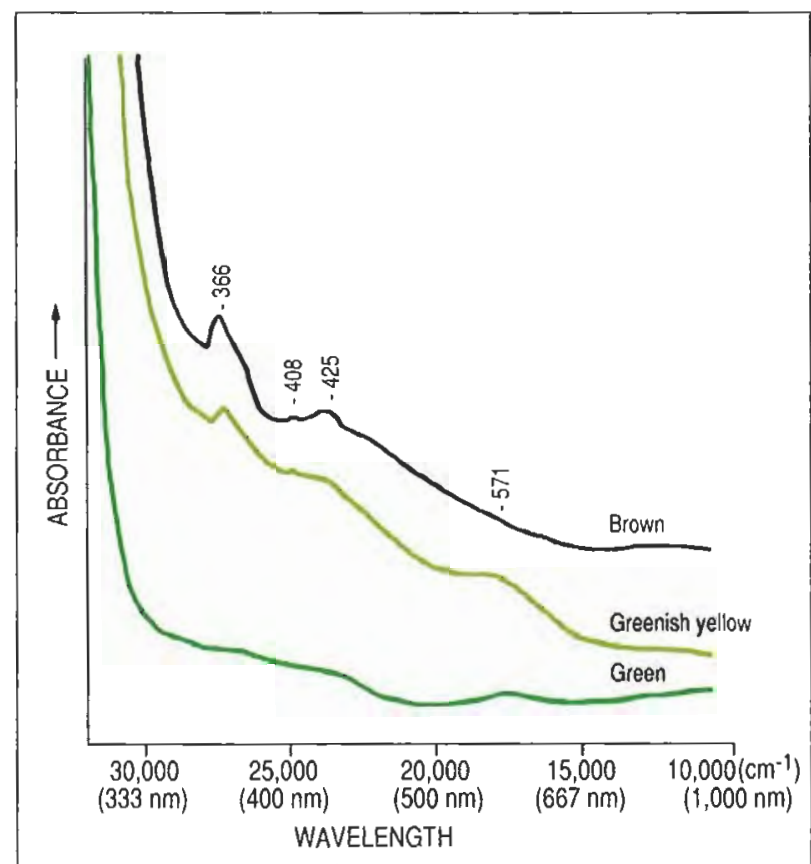

Figure 8. These visible-range optical absorption spectra illustrale typical absorption features found in grossular garnet from the Cocoktau deposit; the absorption bands at 366,408 , and $425 \mathrm{~nm}$ have all been related to the presence of $\mathrm{Fe}^{3+}$ (Manning, 1967). The 571-nm band has also been attributed to $\mathrm{Fe}^{3+}$ in grossular (and $\mathrm{Fe}^{2+}$ in almandine); its behavior here suggests that it is not related to $\mathrm{Fe}^{3+}$.

Figure 9. These three-phase-mineral, liquid, and gas-inclusions are typical of those found in grossular garnel from Altay. Photomicrograph by Fuquan Wang; polarized light, magnified 625x.

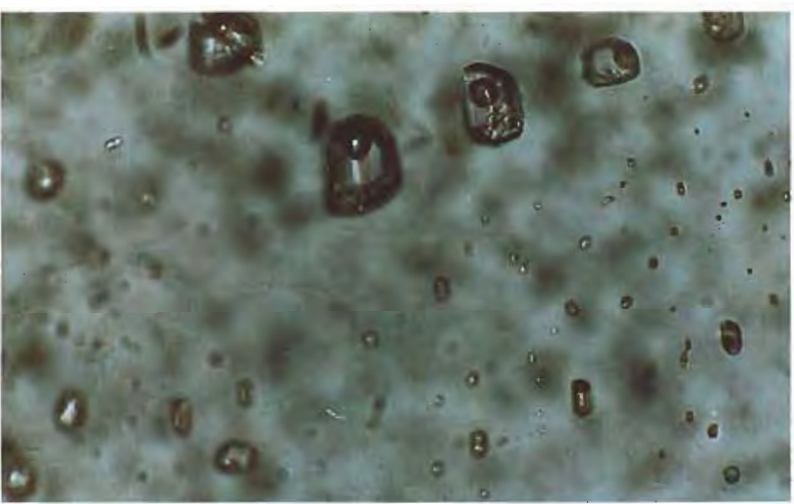

\section{REFERENCES}

Fritsch E., Rossman G.R. (1993) The causes of color in garnets. Mineralogical Record, Vol. 24, No. 1, p. 63.

Keller P.C., Wang F. (1986) A survey of the gemstone resources of China. Gems ev) Gemology, Vol. 22, No. 1, pp. 3-13.

Manning P. G. (1967) The optical absorption spectra of the garnets almandine-pyrope, pyrope and spessartine and some structural interpretations of mineralogical significance. Canadian Mineralogist., Vol. 9, pp. 237-251.
Rickwood P. C. (1968) On recasting analyses of garnet into endmember molecules. Contributions to Mineralogy and Petrology, Vol. 18, pp. 175-198.

Stockton C.M., Manson D.V. (I985) A proposed new classification for gem-quality garnets. Gems e) Gemology, Vol. 21, No. 4, pp. 205-218.

Wang F. (1986) A gemological study of some garnets in China. Acta Geologica, Vol. 60, No. 2, pp, 151-164. 